\title{
DAMPAK PEMANASAN GLOBAL TERHADAP EKOSISTEM PESISIR DAN LAUTAN
}

\author{
Husain Latuconsina \\ Staf Pengajar FPIK UNIDAR Ambon,e-mail: husainlatuconsina@ymail.com
}

\begin{abstract}
ABSTRAK
Fenomena pemanasan global dan menipisnya lapisan Ozon akibat peningkatan emisi gas rumah kaca secara berlebihan di atmosfer melalui penggunaan bahan bakar fosil, deforestasi dan aktivitas manusia lainnya, telah berdampak negatif bagi keberlanjutan ekosistem pesisir dan lautan, diantaranya; (i) komunitas terumbu karang mengalami pemutihan (coral bleaching) sehingga menurunkan produksi perikanan karang (ii) meningkatnya radiasi ultraviolet- $B$ yang masuk ke perairan sehingga menghambat proses fotosintesis dan pertumbuhan fitoplankton sebagai produsen primer dan penyerap $\mathrm{CO}_{2}$ terbesar di perairan laut, (iii) terancamnya hewan laut dari kepunahan akibat meningkatnya suhu dan penurunan salinitas perairan laut, dan (iv) naiknya permukaan laut akibat mencairnya es di kawasan kutub bumi dapat merendam kawasan pesisir dan menenggelamkan pulau-pulau kecil. Semuanya berpotensi mengancam keberlangsungan eksositem pesisir dan lautan sebagai penyangga kehidupan manusia. Untuk itu upaya menekan laju pemanasan global dengan mengurangi penggunaan bahan bakar fosil dan mengurangi tingginya tingkat deforestasi serta minimalisasi aktivitas lainnya yang menghasilkan emisi gas rumah kaca secara berlebihan merupakan tindakan nyata yang harus segera dilakukan sebelum semuanya terlambat.
\end{abstract}

\section{Kata Kunci: Pemanasan global, emisi gas rumah kaca, ekositem pesisir dan lautan}

\section{PENDAHULUAN}

Beberapa dekade terakhir, keprihatinan dunia Internasional terhadap fenomena perubahan iklim global (global climate change) semakin tinggi, karena telah memberikan dampak negatif terhadap keberlanjutan kehidupan di muka bumi akibat meningkatnya temperatur bumi yang dikenal dengan pemanasan global (global warming).

Pemanasan global terjadi akibat meningkatnya emisi gas rumah kaca seperti karbon dioksida $\left(\mathrm{CO}_{2}\right)$, metana $\left(\mathrm{CH}_{4}\right)$, nitrogen oksida $\left(\mathrm{NO}_{\mathrm{x}}\right)$, chlorofluorocarbon (CFC) dan gas lainnya secara berlebihan di atmosfer, sehingga cahaya matahari yang dipantulkan bumi sebagai radiasi infra merah gelombang panjang dan ultraviolet yang akan diteruskan ke angkasa luar, namun sebagian besar dipantulkan kembali ke bumi oleh gas rumah kaca yang terbentuk di atmosfer, sehingga semakin meningkatkan temperatur bumi.

Disebut gas rumah kaca karena beberapa gas yang terbentuk di atmosfer bumi ini berfungsi seperti kaca pada rumah kaca, yang berperan meneruskan cahaya matahari namun menangkap energi panas dari dalamnya. Dengan semakin besar konsentrasi gas rumah kaca di atmosfer, akan semakin besar pula energi panas yang terperangkap di permukaan bumi. 
Emisi gas rumah kaca lebih banyak dihasilkan dari aktivitas manusia yang menggunakan bahan bakar fosil berupa minyak bumi, batu bara dan gas alam dalam bentuk asap dari knalpot kendaraan bermotor dan buangan gas dari cerobong asap pabrik. Kebakaran hutan juga berkontribusi besar bagi pelepasan emisi $\mathrm{CO}_{2}$ ke atmosfer, sementara itu penggundulan hutan menjadi penyebab berkurangnya penyerapan $\mathrm{CO}_{2}$ oleh vegetasi.

Disamping itu, lapisan Ozon $\left(\mathrm{O}_{3}\right)$ yang terbentuk secara alamiah melalui reaksi fotokimia molekul oksigen pada lapisan Stratosfer dengan ketebalan kurang lebih $3 \mathrm{~mm}$ yang terletak pada ketinggian 15 sampai $40 \mathrm{~km}$ di atas permukaan bumi, yang berfungsi sebagai filtrasi terhadap sekitar $80 \%$ radiasi sinar ultraviolet bergelombang pendek dan berenergi tinggi sebelum masuk ke permukaan bumi, kenyataannya dalam beberapa dekade terakhir telah mengalami penipisan akibat penggunaan CFC secara berlebihan oleh manusia. Hasil pengukuran para ilmuan telah membuktikan terjadinya peningkatan sinar ultraviolet-B ke permukaan bumi sebanyak $30 \%$, yang berdampak buruk terhadap manusia dan makhluk hidup lainnya.

\section{GAS RUMAH KACA DAN MEKANISME PEMANASAN GLOBAL}

Terdapat beberapa gas di atmosfir yang berfungsi sebagai 'perangkap' energi panas matahari. Tanpa gas-gas ini, panas akan hilang ke angkasa dan temperatur rata-rata bumi dapat menjadi lebih dingin, karena fungsinya sebagai penjaga hangatnya bumi. Gas-gas ini disebut sebagai Gas Rumah Kaca (GRK), diantaranya; carbon dioksida $\left(\mathrm{CO}_{2}\right)$, metana $\left(\mathrm{CH}_{4}\right)$, nitrogen oksida $\left(\mathrm{NO}_{\mathrm{x}}\right)$ yang terdiri dari gas nitrogen monoksida (NO) dan nitrogen dioksida $\left(\mathrm{NO}_{2}\right)$, chloroflourocarbon (CFC) yang terbagi meliputi haloflourocarbon (HFC) dan perfluorocarbon (PFC).

$\mathrm{CO}_{2}$ merupakan GRK yang paling dominan dalam menahan radiasi bumi sehingga temperatur udara meningkat. Menurut Manik (2007), emisi $\mathrm{CO}_{2}$ terutama berasal dari pembakaran bahan bakar fosil (minyak bumi, gas alam dan batu bara). Sedangkan sumber emisi NOX dan $\mathrm{CH} 4$ terutama bersal dari bahan bakar fosil dan pembakaran bahan organik. Sementara itu CFC merupakan zat kimia ciptaan manusia yang banyak digunakan sebagai zat pendingin dalam kulkas dan AC, industri plastik busa, gas pendorong pada kemasan aerosol (pewangi, hairspray, pembersih kaca dan lainnya) yang berperan terhadap penipisan lapisan Ozon pada atmosfer bumi.

Konsentrasi GRK di atmosfer mampu menyerap sinar inframerah yang dipantulkan bumi sehingga meningkatkan efek rumah kaca yang menyebabkan pemanasan global. Permasalahan ini berkaitan dengan waktu tinggal gas rumah kaca di atmosfer, dimana makin panjang waktu tinggal gas rumah kaca dalam atmosfer maka akan semakin efektif pula pengaruhnya terhadap peningkatan temperatur bumi. Waktu terpanjang emisi gas rumah kaca di atmosfer adalah $\mathrm{CO}_{2}$ sekitar 50-200 tahun, sementara waktu terpendek adalah $\mathrm{CH}_{4}$ yaitu sekitar 10 tahun.

Efek Rumah Kaca sebenarnya berperan penting dalam mendukung kelangsungan hidup manusia dan makhluk hidup lainnya di bumi, karena menurut Soemarwoto (2004) tanpa adanya efek rumah kaca maka bumi akan terlalu dingin untuk ditempati, dengan rata-rata temperatur sekitar $-18^{\circ} \mathrm{C}$, tetapi dengan adanya efek ini temperatur rata-rata bumi menjadi $33^{\circ} \mathrm{C}$ yang sesuai bagi kehidupan makhluk hidup. Namun akan timbul permasalahan apabila efek tersebut terlalu besar, karena bumi akan menjadi lebih hangat dari semestinya dan dapat 
berdampak negatif bagi kehidupan makhluk hidup di muka bumi.

Proses terjadinya pemanasan global berawal dari matahari sebagai sumber energi di muka bumi. Sebagian besar energi tersebut dalam bentuk radiasi gelombang elektromagnetik yang pendek, termasuk cahaya tampak. Ketika energi ini mengenai permukaan bumi, akan berubah dari cahaya menjadi panas yang menghangatkan bumi dan permukaan bumi akan menyerap sebagian panas serta memantulkan kembali sisanya. Sebagian dari panas ini sebagai radiasi infra merah gelombang panjang dan ultraviolet ke angkasa luar. Namun sebagian panas tetap terperangkap di permukaan bumi karena dipantulkan oleh sejumlah gas rumah kaca yang terbentuk di atmosfer, menyebabkan panas tersebut tersimpan di permukaan bumi. Mekanisme ini terjadi secara terus menerus, mengakibatkan temperatur ratarata tahunan bumi mengalami peningkatan.

Ahli klimatologi memprediksikan laju kenaikan emisi GRK akan terus mengalami peningkatan di atmosfer pada masa mendatang yang memacu peningkatan temperatur bumi. Dimana menurut laporan pemantauan Intergovernmental Panel on Climate Change (IPCC) dalam Indrawan et al (2007), telah terjadi kenaikan temperatur bumi sebesar $0,5^{\circ} \mathrm{C}$ selama abad 20 dan diperkirakan akan meningkat sekitar $1,5^{\circ}$ 5,8 ${ }^{\circ} \mathrm{C}$ pada tahun 2100 , bahkan akan mengalami peningkatan lebih besar lagi apabila kadar $\mathrm{CO}_{2}$ meningkat lebih cepat di atmosfer.

Dampak pemanasan global karena peningkatan temperatur bumi adalah berubahnya iklim global berupa perubahan curah hujan dan naiknya intensitas frekwensi badai, naiknya paras laut akibat memuainya air laut pada temperatur yang lebih tinggi dan akibat mencairnya es abadi di kawasan kutub bumi, salinitas menurun dan sedimentasi meningkat di kawasan pesisir dan lautan, sehingga semakin mengancam keberlanjutan sumberdaya alam pesisir dan laut sebagai penyangga kehidupan manusia.

\section{DAMPAK BAGI KOMUNITAS TERUMBU KARANG}

Pemanasan global telah

menyebabkan penurunan keanekaragaman hayati laut. Salah satunya terjadi pada komunitas terumbu karang dari jenis hermatifik (hermatypic coral), yaitu hewan karang pembentuk bangunan/kerangka karang dari tumpukan kapur $\left(\mathrm{CaCO}_{3}\right)$ sebagai hasil fotosintesis jutaan alga zooxanthellae yang hidup bersimbiosis dalam jaringan tubuh hewan karang tersebut.

Terumbu karang merupakan komunitas biologis di perairan laut dangkal yang umumnya berkembang secara optimal pada temperatur perairan $25-29^{\circ} \mathrm{C}$ dan sangat rentan terhadap perubahan temperatur perairan yang merupakan salah satu faktor pengontrol pertumbuhan dan perkembangan karang. Sehingga kenaikan temperatur $1^{\circ} \mathrm{C}$ saja polip karang mengalami stress berat dan jika berlangsung dalam waktu lama (3-6 bulan), akan menyebabkan lepasnya alga zooxanthellae dalam tubuh hewan karang, dimana peristiwa ini disebut pencucian/pemutihan karang (coral bleaching). Belum banyak yang dimengerti dari mekanisme coral bleaching, namun menurut Westmacott et al, (2000) diperkirakan kenaikan suhu menganggu kemampuan zooxanthellae untuk berfotosintesis, dan dapat memacu produksi kimiawi berbahaya yang merusak sel-sel mereka.

Hewan karang akan mengalami kehilangan 60-90\% dari jumlah alga zooxanthellae-nya dan alga zooxanthellae yang masih tersisa dapat kehilangan 50$80 \%$ dari pigmen fotosintesisnya selama peristiwa coral bleaching (Glynn, 1996) dalam Westmacott et al. (2000). Menurut Supriharyono (2007), laju kalsifikasi (produksi kapur $\mathrm{CaCO}_{3}$ ) akan meningkat seiring meningkatnya laju fotosintesis alga 
zooxanthellae. Sebaliknya dengan terhambatnya fotosintesis, akan menurunkan laju kalsifikasi dan petumbuhan karang menjadi lambat. Dahuri (2003) menambahkan bahwa meningkatnya emisi $\mathrm{CO}_{2}$ di atmosfer, turut mempengaruhi perubahan senyawa kimia karbon di permukaan laut sehingga mempengaruhi penurunan $\mathrm{pH}$ dan konsentrasi ion karbonat, yang dapat menurunkan kejenuhan $\mathrm{CaCO}_{3}$. Bahkan peningkatan $\mathrm{CO}_{2} \quad$ menyebabkan berkurangnya laju kalsifikasi, sehingga menurunkan kemampuan adapatasi karang terhadap peningkatan paras laut.

Meningkatnya temperatur perairan laut diluar batas normal, tingginya intensitas sinar ultraviolet, meningkatnya kekeruhan dan sedimentasi, serta kondisi salinitas yang tidak normal merupakan beberapa faktor penyebab terjadinya coral bleaching. Namun mayoritas penyebabnya secara besar-besaran dalam dua dekade terakhir lebih disebabkan oleh peningkatan temperatur perairan laut. Menurut Westmacott et al, (2000) dampak gabungan dari tingginya temperatur permukaan laut dan intensitas sinar matahari pada gelombang panjang ultraviolet dapat mempercepat coral bleaching dengan mengalahkan mekanisme alami karang untuk melindungi diri dari sinar matahari yang berlebihan.

Fenomena coral bleaching dalam beberapa dekade terakhir telah terjadi hampir di seluruh perairan laut dunia. Menurut survei tahun 1982 dan 1983 lautan pasifik mengalami kenaikan suhu, mengakibatkan coral bleaching sehingga menurunkan sekitar 70-95\% terumbu karang di daerah tersebut (Primack et al, 1998). Sementara itu, Westmacott et al (2000) melaporkan bahwa sepanjang tahun 1998 telah terjadi dii kawasan Asia-Pasifik yang sangat parah kondisi terumbu karangnya akibat bleaching, dengan tingkat kerusakan mencapai 75-90 \% dari total terumbu karang yang berada pada kawasan ini.
Permasalahan serupa dilaporkan Burke et al, (2002), bahwa perubahan iklim global berpotensi mengancam keberadaan terumbu karang di kawasan Asia Tenggara, dimana peristiwa El Nino Southern Oscillation (ENSO) tahun 1997-1998 telah memacu peristiwa coral bleaching yang terbesar sepanjang sejarah, dan diperkirakan $18 \%$ terumbu karang kawasan Asia Tenggara telah rusak parah. Wilkinson et al, (1999) dalam Indrawan et al, (2007) juga melaporkan bahwa hingga akhir 1990-an telah terjadi coral bleaching sebesar $30 \%$ di Indonesia. Di kepulauan Seribu misalnya, sekitar $90-95 \%$ terumbu karang hingga kedalaman $25 \mathrm{~m}$ telah mengalami kematian akibat hal yang sama.

\section{DAMPAK BAGI FITOPLANKTON DAN BIOTA LAUT LAINNYA}

Dalam proses fotosintesis di lautan, fitoplankton dapat mengikat secara langsung $\mathrm{CO}_{2}$ dari atmosfer sebagai bahan dasar untuk kelangsungan proses fotosintesis yang menghasilkan $\mathrm{O}_{2}$ terlarut untuk kebutuhan biota laut lainnya dalam proses respirasi. Menurut Dahuri (2003), fitoplankton juga berfungsi sebagai biological carbon pump yang mampu menyerap $\mathrm{CO}_{2}$ dari atmosfer dan pada kolom perairan, dikarenakan laut dalam akan melakukan resirkulasi $\mathrm{CO}_{2}$ ke permukaan laut yang kemudian dapat melepaskannya ke atmosfer, sehingga jika fitoplankon mengalami kematian masal maka akan menurunkan penyerapan $\mathrm{CO}_{2}$, menyebabkan kandungan $\mathrm{CO}_{2}$ di atmosfer dan di kolom perairan akan meningkat drastis 2-3 kali lipat sekitar 1 abad kedepan.

Menurut Nontji (2008), kemampuan fitoplankton laut untuk menyerap $\mathrm{CO}_{2}$ dari atmosfer tidak kalah besarnya dengan kemampuan seluruh tumbuhan yang ada di daratan dalam menyerap $\mathrm{CO}_{2}$, karena fitoplankton laut dapat menyerap sekitar 40-50 miliar ton karbon per tahun dan memiliki peranan penting dalam menjaga kesimbangan panas bumi melalui 
pengontrolan perluasan dan ketebalan awan yang melewati lautan sehingga dikenal sebagai pengatur dan pengendali iklim global. Dengan demikian, tanpa kehadiran fitoplankton di lautan maka temperatur bumi akan menjadi lebih panas dari semestinya, yang menyebabkan bumi tidak layak untuk dihuni oleh makhluk hidup.

Fitoplankton di lautan tidak saja mampu mengendalikan dan mengatur iklim global, namun juga menerima dampak negatif dari perubahan iklim akibat pemanasan global. Menurut Syamsuddin (2000), menipisnya lapisan Ozon telah berdampak buruk terhadap komunitas fitoplankton di lautan akibat peningkatan emisi GRK berupa CFC. Diperkirakan 16 $\%$ pengurangan lapisan Ozon akan mengakibatkan terhambatnya pertumbuhan fitoplankton sebagai dasar rantai makanan sehingga menurunkan laju fotosintesis di laut yang diperkirakan sudah mencapai 6-12\%.

Dengan semakin kecil ukuran individu dan populasi fitoplankton, akan menurunkan produktivitas primer yang menyebabkan terganggunya sistem rantai makanan di perairan laut, karena fitoplankton merupakan penghasil bahan organik dan sumber produsen utama di perairan laut. Sehingga akan berpengaruh langsung terhadap penurunan populasi zooplankton sebagai konsumennya dan selanjutnya berpotensi terhadap penurunan kelimpahan ikan sebagai konsumen pada tingkatan selanjutnya.

Radiasi UV-B secara berlebihan menurut Syamsuddin (2000), juga dapat menyebabkan rekombinasi gen, memperlambat pembelahan sel sehingga menghambat laju pertumbuhan biota laut dan merusak sistem kekebalan hewan laut, terhambatnya reproduksi generatif beberapa hewan laut melalui inaktivasi selsel organ reproduksi berupa kerusakan kromosom kelamin dari sel telur dan spermatozoa, sehingga berpotensi merubah rasio perbandingan individu jantan dan betina. Dapat pula menurunkan daya tetas telur biota laut, kerusakan jaringan tubuh, penurunan laju pertumbuhan dan laju pembentukan cangkang hewan avertebrata laut, serta menghambat penyerapan unsur hara seperti nitrogen bagi alga laut yang menyebabkan menurunnya kuantitas dan kualitas kandungan agar dan karagenan.

Berdasarkan pemantauan biota laut oleh Eliot dan Simmonds pada tahun 2007 dalam Indrawan et al (2007), telah dianalisis dan diperkirakan sejumlah dampak langsung akibat perubahan temperatur bumi yaitu terjadinya perubahan pola distribusi dari beberapa jenis mamalia laut yang berpindah menuju habitat optimalnya yang tersisa dan dapat mempengaruhi kerentanan peyebaran virus dan introduksi kuman penyakit. Sementara dampak tidak langsung adalah perubahan ketersediaan dan kelimpahan sumber pakan.

Dengan demikian, dikhawatirkan akan terjadi penurunan tingkat keanekaragaman biota laut di dunia secara besar-besaran karena mengalami kerentanan dan ancaman kepunahan. Dimana pemanasan global telah menyebabkan beberapa parameter fisika dan kimia lingkungan sebagai faktor pembatas akan mengalami perubahan drastis yang tidak ideal lagi bagi sebagian besar biota laut untuk dapat berkembang dan bertahan hidup.

\section{DAMPAK BAGI KAWASAN PESISIR DAN PULAU-PULAU KECIL}

Ketika atmosfer menghangat, lapisan permukaan lautan akan ikut menghangat, sehingga memacu kenaikan paras laut. Pemanasan global juga telah mencairkan banyak Es di kawasan kutub bumi terutama di sekitar Greenland. Tinggi paras laut di seluruh dunia telah meningkat $10-25 \mathrm{~cm}$ selama abad ke-20. IPCC memprediksi peningkatan paras laut lebih lanjut sekitar 1 m pada akhir abad ke-21.

Hasil penelitian Fred Pearce tahun 2002 dalam Indrawan et al (2007), 
membuktikan bahwa lapisan Es yang menyelimuti permukaan bumi telah berkurang $10 \%$ sejak tahun 1960, sementara ketebalan Es di kawasan Kutub Utara telah berkurang $42 \%$ dalam 40 tahun terakhir. Artinya, ancaman hilangnya daratan Es di kawasan Kutub bumi bukanlah sesuatu yang mustahil terjadi jika pemanasan global terus meningkat dari tahun ke tahun.

IPCC pada tahun 1990 telah membuat skenario terkait kenaikan paras laut, dimana jika tidak terjadi upaya manusia untuk mengurangi emisi gas rumah kaca, khususnya $\mathrm{CO}_{2}$, maka paras laut akan naik kira-kira $1 \mathrm{~m}$ pada akhir abad ke-21 (2100), namun jika umat manusia sepakat mengurangi emisi gas rumah kaca pada tahun 2025 (berdasarkan Protokol Kyoto), maka paras laut masih tetap naik sekitar $60 \mathrm{~cm}$. Disebabkan $\mathrm{CO}_{2}$ merupakan gas yang dapat tetap bertahan di atmosfer selama 100 tahun lebih, sebelum akhirnya diambil oleh tumbuhan atau dihilangkan oleh proses geokimia.

Penyusutan lapisan es di Greenland diproyeksikan berdampak besar terhadap naiknya paras laut pada abad ke-22 dan lapisan Es tersebut akan habis jika pemanasan global rata-rata sebesar 1,9 $4,6{ }^{\circ} \mathrm{C}$ terus berlangsung selama $10 \mathrm{abad}$, menyebabkan peningkatan paras laut sebesar $7 \mathrm{~m}$, yang berpotensi merendam kawasan pesisir dan menenggelamkan pulau-pulau kecil. Sehingga akan mengancam negara-negara pulau seperti Singapura, Palau dan Belanda, atau negara kepulauan yang berukuran kecil di kawasan Pasifik seperti kepulauan Fiji, Bahama dan Santa Lusia dan lainnya.

Menurut Rais et al (2004), dampak yang diperkirakan dapat terjadi dengan naiknya paras laut, diantaranya; meningkatnya abrasi pantai, banjir di wilayah pesisir yang lebih buruk, tergenangnya lahan basah pada wilayah pesisir, meningkatnya salinitas estuaria, berubahnya kisaran pasang-surut di sungai dan teluk, dan tenggelamnya terumbu karang.

Permasalahan serupa akan dialami Indonesia sebagai negara kepulauan terbesar di dunia yang terdiri dari 17.508 buah pulau dan sebagian besarnya merupakan pulau-pulau kecil akan berpotensi kehilangan banyak pulau akibat kenaikan paras laut. Hasil simulasi oleh Armi Susandi dari Institut Teknologi Bandung dalam Dault (2008) untuk mengetahui ancaman tenggelamnya pulaupulau dan daratan pesisir di Indonesia, menunjukkan bahwa pada tahun 2100 sekurang-kurangnya 115 pulau yang berada pada kepulauan Riau, Sulawesi, Maluku dan pantai Utara Jawa akan tenggelam dan terendam air laut.

Fenomena naiknya paras laut akibat pemanasan global akan mengancam kehidupan manusia dan komunitas biotik lainnya, dimana secara perlahan kawasan pesisir akan mengalami perubahan fungsional dan resiko kehilangan biota yang hidup pada lingkungan tersebut akan sangat besar. Selain itu kawasan pesisir yang berperan penting sebagai pusat berbagai aktifitas sosial ekonomi manusia, seperti; perindustrian, pertambangan, pertanian, perikanan, pemukiman penduduk, perhotelan, pariwisata, kawasan konservasi dan jasa kepelabuhanan akan terganggu akibat ancaman terendam oleh kenaikan paras laut.

\section{PENUTUP}

Pemanasan global telah menjadi isu utama dunia internasional karena berkaitan dengan keberlanjutan dan perkembangan bumi sebagai tempat hidup manusia dan makhluk hidup lainnya pada masa kini dan di masa yang akan datang. Untuk itu, upaya mengurangi laju pemanasan global wajib dan segera dilakukan, melalui ;

- Penyusunan berbagai kebijakan terkait pengelolaan lingkungan hidup yang berorientasi pada upaya pengurangan laju pemanasan global. Seperti menekan tingginya tingkat deforestasi 
pada sektor kehutanan, melalui penetapan jeda tebang hutan. Indonesia sebagai negara berkembang dan salah satu negara dengan potensi hutan tropis terbesar di Dunia, dapat menggunakan Clean Developmen Mechanism (salah satu mekanisme fleksibel dalam protokol kyoto) untuk mendukung pelaksanaan program kehutanan nasional seperti rehabilitasi lahan dan kegiatan penanaman hutan terdegradasi, meliputi; pengentasan kemiskinan masyarakat di sekitar hutan, pemberantasan Illegal Logging, pelaksanaan pengelolaan hutan lestari melalui sertifikasi hutan, rehabilitasi dan konservasi sumberdaya hutan. Apabila program ini berjalan dengan baik diharapkan Indonesia dapat mengambil keuntungan dengan menjual hak polusi yang tidak digunakannya kepada negara industi maju sebagai bentuk mekanisme perdagangan emisi (Emission Trading) yang termasuk salah satu mekanisme fleksibel dalam Protokol Kyoto untuk mencegah atau mengurangi emisi GRK.

- Pengurangan emisi GRK secara di atmosfer, melalui pengembangan teknologi pembangkit listrik berbasis energi terbaharukan dengan memanfaatkan potensi alam pesisir dan laut, seperti; energi pasang surut, energi gelombang laut, energi angin laut dan Ocean Thermal Energi Conversion (OTEC) sebagai pengganti penggunaan energi fosil penghasil emisi GRK. Strategi ini diharapkan dapat menanggulangi krisis energi di masa mendatang. Walaupun pengembangan teknologi ini membutuhkan investasi yang sangat besar, namun rekomendasi Protokol Kyoto yang disebut Clean Development Mechanism (CDM) dapat dijadikan solusi. CDM merupakan salah satu mekanisme fleksibel untuk membantu negara industri maju memenuhi komitmennya mengurangi emisi GRK melalui pelibatan negara berkembang karena berdasarkan Protokol Kyoto negara berkembang tidak memiliki kewajiban membatasi emisi GRK-nya, namun dapat secara sukarela berpartisipasi mengurangi emisi global dengan menjadi tempat pelaksanaan proyek CDM, sehingga dapat memberikan keuntungan bagi negara berkembang seperti Indonesia, melalui pengurangan biaya investasi dan mendapatkan transfer teknologi berbasis energi terbaharukan yang ramah lingkungan dan berkelanjutan.

- Pencegahan penipisan lapisan Ozon yang diperkirakan sudah mencapai 30 $\%$ lebih, melalui komitmen bersama untuk mengurangi penggunaaan dan membatasi produksi CFC dengan pengembangan bahan alternatif pengganti CFC yang ramah lingkungan untuk pendukung aktivitas manusia. Upaya ini dilakukan agar lapisan Ozon sebagai filtrasi radiasi sinar matahari yang masuk ke Bumi dapat tetap terjaga demi keberlanjutan kehidupan di muka Bumi, karena walaupun upaya minimalisasi penggunaan $\mathrm{CFC}$ telah dilakukan, namun manfaatnya belum dapat dirasakan dalam waktu singkat, disebakan konsentrasi CFC sekitar 8 juta ton yang dilepaskan ke udara selama kurun waktu 50 tahun terakhir hampir seluruhnya masih berada di atmosfer. Sehingga dibutuhkan waktu yang sangat lama agar senyawa CFC ini dapat dihilangkan melalui proses geokimia.

- Pemantauan komunitas fitoplankton di lautan secara simultan dan berkesinambungan untuk mengetahui pengaruh pemanasan global terhadap perkembangan komunitas fitoplankton. Peranan fitoplankton yang sangat besar dalam mengendalikan iklim global melalui kemampuannya menyerap $\mathrm{CO}_{2}$ secara langsung baik dari atmosfer 
maupun kolom perairan untuk kebutuhan proses fotosintesisnya, sehingga upaya mempertahankan komunitas fitoplankton di lautan baik dalam ukuran maupun kelimpahnnya sangat diperlukan. Dalam beberapa percobaan ilmiah pernah dilakukan pemupukan di Samudera Selatan dekat Antartika pada area seluas $300 \mathrm{~km}^{2}$ dengan menggunakan unsur besi $(\mathrm{Fe})$ dan dalam waktu delapan minggu telah menghasilkan produkstivitas primer sebesar 10 kali lipat, sehingga ikut meningkatkan kemampuan fitoplankton dalam menyerap $\mathrm{CO}_{2}$.

- Pengembangan budidaya berbagai jenis rumput laut (alga laut), karena selain dikenal sebagai komoditas unggulan yang bernilai ekonomis penting, ternyata dalam berbagai penelitian juga diketahui memiliki kontribusi positif dalam menyerap $\mathrm{CO}_{2}$ langsung dari atmosfer maupun dari kolom perairan sehingga membantu pengontrolan kadar $\mathrm{CO}_{2}$ di bumi. Khusus bagi Indonesia sebagai negara bahari yang memiliki banyak teluk, selat dan pulau-pulau kecil serta memiliki luas laut teritorial 3,1 juta $\mathrm{km}^{2}$, menjadikan usaha budidaya alga laut sangat prospektif untuk dikembangkan, sehingga dapat meningkatkan pendapatan masyarakat pesisir, dan secara tidak langsung turut memberikan manfaat dalam upaya mengurangi laju pemanasan global.

\section{DAFTAR PUSTAKA}

Burke,L., E. Selig, and M. Spalding. 2002. Terumbu Karang yang Terancam di Asia Tenggara. World Resources Institute.Washington DC. USA.

Callan, S.J. and J.M.,Thomas. 2000. Environmental Economics and Management: Theory, Policy, and Applications, The Dryden Press.

Dahuri, R. 2003. Keanekaragaman Hayati Laut ; Aset Pembangunan Berkelanjutan. PT. Gramedia Pustaka Utama. Jakarta.

Dault, A. 2008. Pemuda dan Kelautan. PT. Pustaka Cidesindo. Jakarta.

Glynn, P.W. 1996. Coral reef bleaching: facts, hypothesis and implications. Global Change Biology.

Harijono, S.W.B. 2007. Kondisi Indonesia Saat ini dan Prediksi Iklim Masa yang Akan Datang. Diskusi Panel Kesiapan Indonesia Menghadapi Perubahan Iklim. Badan Meteorologi dan Geofisika. Jakarta.

Ikawati, Y., P.S.Hanggarwati., H.Parlan., H. Handini dan B.Siswodihardjo. 2001. Terumbu Karang di Indonesia. Penerbit MAPIPTEK, Jakarta.

Indrawan, M., R.B. Primack, dan J. Supriatna. 2007. Biologi Konservasi (Edisi Revisi). Yayasan Obor Indonesia, Jakarta. 